\title{
Revisiting Death's Difference: The Philosophical Anthropology of the U.S. Death Penalty AND THE IMPOSSIBILITY OF CAPITAL DUE Process
}

\author{
G.P. Marcar*
}

\begin{abstract}
Within the United States, legal challenges to the death penalty have held it to be a "cruel and unusual" punishment (contrary to the Eighth Amendment) or arbitrarily and unfairly enacted (contrary to the Fifth and Fourteenth Amendments). The Eighth Amendment requires that punishments not be disproportionate or purposeless. In recent rulings, the U.S. Supreme Court has adopted a piecemeal approach to this matter. In regard to particular classes of defendant, the Court has sought to rule on whether death is likely to be a proportional and purposeful punishment, as well as whether-given the condition of these defendants-such a determination can be reliably and accurately gauged. This article will suggest a different approach. Instead of asking whether, given the nature of certain categories of human defendant, the death penalty is constitutional in their case, I will begin by asking what-given the nature of the U.S. death penalty - one must believe about human beings for death to be a proportionate punishment. From this, I will argue that to believe that these penal goals are capable of fulfilment by the death penalty entails commitment to an empirically unconfirmable philosophical anthropology. On this basis, it will be further argued that the beliefs required for the U.S. death penalty's proportional and purposeful instigation (pursuant to the Eighth Amendment) are not congruent with the demands of legal due process.
\end{abstract}

KEYWORDS

Capital Punishment, Proportionality, Eighth Amendment, Due Process, Death Penalty, Philosophical Anthropology

\section{CONTENTS}

I. INTRODUCTION 183

II. A Brief Account of the U.S. Supreme Court's Recent “Death is

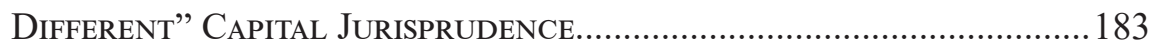

A. The Severity of Death as a Penal Sentence ................................ 184

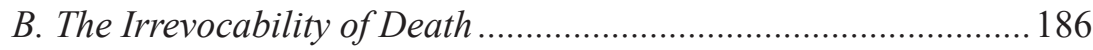

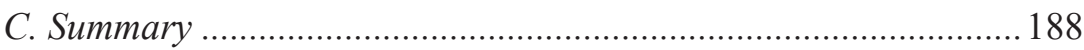

* Ph.D., Centre for Theology and Public Issues, University of Otago, New Zealand 
III. The Penal Goals of the State’s Ultimate Punishment

A. Deterrence

B. Retribution

1. Outrage-Based Retribution

2. The Weight of Death: An Especially Severe Punishment

3 The Weight of the State: An Especially Severe Punisher

4. Summary

C. Incapacitation

1. The Court's Jurisprudence of Dangerous Capital Defendants:

Coker, Ramos and Tison

2. The Proportionality of Incapacitation

D. Summary: Penal Goals and the Philosophical Anthropology of

Capital Punishment

IV. Conscientious Beliefs and the Impossibility of CAPITAL Due

Process . .204

V. Conclusion 207 


\section{INTRODUCTION}

Capital punishment remains popular in the United States. Depending upon the particular question asked and methodology used, polling indicates that although support for the death penalty does appear to be declining slightly in the U.S., it continues to enjoy a clear majority level of support. ${ }^{1}$ Indeed, the status of capital punishment in contemporary America is that it may be regarded, without hyperbole, as a firmly established political and legal tradition. As Peter Hare writes, "[t]he death penalty is inextricably tied up with a huge number of firmly established aspects of American society", to such an extent that it has "become virtually inseparable from various other major features of the American legal, moral, and religious landscape". ${ }^{2}$ Even within the courtroom, the U.S. death penalty possesses a unique status, insofar as those who unequivocally object to this punishment may be excluded from capital jury-selection so as to ensure that the panel is "deathqualified".

Such popularity, or entrenched societal status, however, has not prevented the U.S. death penalty from being subjected to legal challenges. Following the case of Furman v. Georgia (1972), the Court suspended the death penalty in the U.S. until it was shown (in the 1976 case of Gregg v. Georgia) that the practice could be implemented without violating the Eighth Amendment right against cruel and unusual punishments, or the Fourteenth Amendment rights to "due process" and "equal protection" under the law. ${ }^{3}$ After first briefly examining some of the Court's most impactful post-Furman death penalty rulings, this article will make the case for a new approach. Rather than looking at particular defendants and asking whether the death penalty complies with the Eighth Amendment in their case, this paper will seek to ask what, given capital punishment's commonly-held penal purposes, human beings must be in order for death to ever be a proportionate punishment.

\section{A Brief AcCount of the U.S. Supreme Court's Recent "DEATH is DifFERENT" CAPITAL JuRISPRUDENCE}

In its recent rulings, the U.S. Supreme Court ("the Court") has repeatedly recognised that when considered alongside other punishments, "death is different". As the Court ruled in Furman v. Georgia (1972), "[t] he unusual severity of death is manifested most clearly in its finality and enormity. Death, in these respects, is in a class by itself." Such is the uniqueness of death as a penalty that it must be regarded as "different from all other forms of criminal punishment, not in degree but in kind". ${ }^{5}$ That the death penalty is "unique in its severity and irrevocability"

See instance e.g., Pew Research Center, Less Support for Death Penalty, Especially Among Democrats, Apr. 16, 2015, http://www.people-press.org/2015/04/16/lesssupport-for-death-penalty-especially-among-democrats/.

2 Peter Hare, Pragmatism with Purpose: Selected Writings 270-78 (Joseph Palencik et al. eds, 2015).

3 See Furman v. Georgia, 408 US 238 (1972); Gregg v. Georgia, 428 U.S. 153 (1976).

4 Furman v. Georgia, 408 U.S. 238, 289 (1972).

5 Id. at 306 (Stewart, J., concurring). 
was subsequently reaffirmed by the Court four years later in Gregg v. Georgia. ${ }^{6}$ Whereas the consequences of other punishments are temporally limited for the criminal (for instance, if they are sentenced to a limited number of years in prison) and cannot affect the entirety of a person's subjective experience of the world, the consequences of the death penalty are permanent and all-encompassing, nothing less than the termination of the object itself.

\section{A. The SeVerity of Death as a Penal Sentence}

Since the leading case of Weems v. United States (1910), the Court has consistently recognized that the question of a punishment's proportionality is integral to the matter of whether or not it violates the Eighth Amendment. ${ }^{7}$ One of the first cases in which consideration of death's uniquely irreversible harm was applied to the context of capital punishment's proportionality is Coker v. Georgia (1977). The Court held that although the crime of raping an adult woman was undoubtedly a serious crime, "in terms of moral depravity and of the injury to the person and to the public, it does not compare with murder." "The reason for this divide is simply that murder (by its nature) always involves the death of the victim, whereas rape does not. Whereas the harm caused by murder is thus permanent and irreversible, the Court ruled that following rape, "life may not be nearly so happy as it was, but it is not over, and normally is not beyond repair." "As proportionality demands that there be semblance between the nature of the harm inflicted by the crime and that which is delivered by the punishment, the Court in Coker ruled that the death penalty was an unconstitutionally "excessive" punishment for the crime of rape.

As a result of death's categorical difference, a consistent feature of postGregg jurisprudence in the United States has also been the narrowing of the category of defendant for whom the death penalty is thought an appropriate punishment. This narrowing can be traced to Godfrey v. Georgia (1980), in which the Court ruled against a defendant's execution on the basis that his crime did not reflect "a consciousness materially more 'depraved' than that of any person guilty of murder." 10 Apparent here is the connection drawn by the Court between culpability for action, and depravity of consciousness. The defendant in Godfrey was found guilty of murdering his wife and mother-in-law. The Georgian jury also found that the statutory aggravating factor of his murder being "outrageously or wantonly vile, horrible and inhuman" had been demonstrated beyond a reasonable doubt.

The question before the Court was whether this aggravating factor was correctly found in Godfrey's case. Writing his opinion on behalf of the Court, Justice Stewart took his cue from the Court's previous determination in Furman that the capital sentencer's discretion must be channelled so as to provide a "meaningful basis for distinguishing the few cases in which the penalty is imposed from the many cases

6 Gregg v. Georgia, 428 U.S. 153, 187 (1976). See also Woodson v. North Carolina, 428 U.S. 280, 305 (1976) ("the penalty of death is qualitatively different from a sentence of imprisonment, however long").

7 Weems v. United States, 217 U.S. 349 (1910).

8 Coker v. Georgia, 433 U.S. 584. 598 (1977).

9 Id.

10 Godfrey v. Georgia, 446 U.S. 420, 433 (1980). 
in which it is not." ${ }^{\prime 11}$ By simply stating the above aggravating factor, the Court ruled that the Georgian courts had failed in this obligation. On the basis of the facts before them, the Court concluded that the defendant's actions did not reflect a "materially more 'depraved' consciousness", due to the fact that "[ $t]$ here is no principled way to distinguish this case, in which the death penalty was imposed, from the many cases in which it was not." 12 The aggravating factor that the defendant's crime had been "outrageously or wantonly vile, horrible and inhuman", on which Godfrey had been sentenced to death, should not have been found.

In the beginning of the twenty-first century, this narrowing of defendants has been extended to two general categories: those who are under 17 years old on the day of their crime in Roper v. Simmons (2005), and the mentally retarded in Atkins v. Virginia (2002). In Atkins, the Court ruled that it violated the Eighth Amendment protection against "cruel and unusual punishment" to execute those classified as mentally retarded. ${ }^{13}$ Discussing how the death penalty fails to fulfil the goal of retribution in these cases, Justice Stevens (writing for the Court) first noted that due to lesser capacities in areas of reasoning, judgment and impulse control, those with mental disabilities do not possess the same culpability for their actions as those without these impairments. Directly citing the previous Court's ruling in Godfrey, Justice Stevens stated that "[i]f the culpability of the average murderer is insufficient to justify the most extreme sanction available to the state, the lesser culpability of the mentally retarded offender surely does not merit that form of retribution." 14

Similarly, in Roper v. Simmons, Justice Kennedy cited an "underdeveloped sense of responsibility" (leading to "impetuous and ill-considered actions"), a greater propensity to be influenced by others, and a fluid, unfixed character as three reasons why juveniles should generally be considered neither as culpable, nor as deterrable, as adult offenders. ${ }^{15}$ Focussing on the nature of juveniles' characters, Kennedy wrote that " $[\mathrm{t}]$ he reality that juveniles still struggle to define their identity means it is less supportable to conclude that even a heinous crime committed by a juvenile is evidence of irretrievably depraved character... a greater possibility exists that a minor's character deficiencies will be reformed."16 As a result, although the conduct of these individuals may evoke outrage, they are not of such culpability for their actions (qua agents) that they deserve to be executed. The Court concluded that " $[\mathrm{r}]$ etribution is not proportional if the law's most severe penalty is imposed on one whose culpability or blameworthiness is diminished, to a substantial degree, by reason of youth and immaturity." ${ }^{17}$ The Court here alluded to its previous judgement in Atkins (which in turn drew on Godfrey) in order to suggest that because juveniles commonly exhibit a culpability which is below average, death - which by virtue

Id. at 427 (quoting Furman v. Georgia, 408 U.S. 238, 313 (1972)).

Id. at 433 .

Atkins v. Virginia, 536 U.S. 304 (2002).

$14 I d$. at 319 . In addition, the limited cognitive capacities of mentally retarded individuals, the Court argued, also make them less likely (in principle) to be deterred by even the most severe of penal consequences. As such, neither of the death penalty's two principal penal goals are likely to be proportionately fulfilled in their case. See id. at 319-30.

15 Roper v. Simmons, 543 U.S. 551, 569-72 (2005).

$16 \quad I d$. at 570.

$17 \quad I d$. at 571. 
of its severity requires a criminal culpability and depravity which is greater than average - is not a constitutionally appropriate sentence in their case. ${ }^{18}$

\section{B. THE IRREVOCABILITY OF DEATH}

The other qualitative difference which death possesses over other punishments is its irrevocability as a judicial sentence. Unlike other state measures, once made (and enacted), a death sentence cannot be overturned or reverse if found to be mistaken; nor can the defendant be compensated for the injustice done. The Court has consistently recognised this fact in recent years, leading it to address procedural shortcomings and anomalies with an urgency and seriousness arguably absent from similar cases of a non-capital nature. ${ }^{19}$ This difference of irrevocability, it may be suggested, is secondary and derivative of the previously mentioned difference of death's severity.

Aligned with this awareness of the irrevocability of death as a sentence, the Court in Godfrey, Atkins and Roper can be seen to make procedural and epistemic arguments which, although closely related, are separate from its arguments about the defendants' culpability. As described above, the case in Godfrey centred on the jury in Georgia making (on the basis of insufficient guidance) a determination that the defendant's crime had been "outrageously or wantonly vile, horrible and inhuman." The Court disagreed with the jury's finding, ruling instead that the defendant's consciousness in this case was not evidently "more depraved" than the average murderer's. Evident here are two distinct questions: whether or not the defendant's consciousness was (objectively) more depraved than average, and whether the jury was within its rights to judge the issue. In Godfrey, the Court effectively ruled negatively on both issues. Regarding whether the jury had correctly judged the issue, the Court determined that if an aggravating factor was simply stated to the jury (as happened in Godfrey's case), then they would be insufficiently equipped to assess whether the defendant was of sufficient depravity to be executed. This is because, the Court observed, "[a] person of ordinary sensibility could fairly characterize almost every murder as 'outrageously or wantonly vile, horrible and inhuman.'" ${ }^{20}$ Appropriate judicial guidance is thus to ensure that only the worst defendants receive the law's most severe punishment.

In ruling on the constitutionality of executing particular classes of defendants, the Court in Atkins and Roper can be seen to follow this belief that judicial safeguards must be adequate if juries are to be prevented from making fatally incorrect decisions. In Atkins for instance, the Court does not rule that the state execution

$18 \quad I d$. Although Justice Kennedy does not directly cite the Court's dicta in Godfrey (referring only to it indirectly through Atkins), the thematic thread running from Godfrey, through Atkins to Roper is also picked up by Justice O'Connor, who argues in her dissenting opinion that (contrary to the Court's insulation), the defendant's actions in this case "unquestionably reflect 'a consciousness materially more 'depraved' than that of '... the average murderer." $I d$. at 601.

19 See e.g., Woodson v. North Carolina, 428 U.S. 280, 304 (1976); Batson v. Kentucky, 476 U.S. 79 (1986); Simmons v. South Carolina, 512 U.S. (1994); Miller-El v. Cockrell, 537 U.S. 322 (2003); Wiggins v. Smith, 539 U.S. 510 (2003); Banks v. Dretke, 540 U.S. 668 (2004).

20 Godfrey v. Georgia, 446 U.S. 420, 428 (1980). 
of someone could never be a justified punishment. Rather, the Court argues that because of the cognitive difficulties it has listed in relation to mentally retarded persons' diminished culpability, these defendants may also be at a particular "risk" of unjust execution. This is due, in part, to them having a greater propensity to make false confessions to the police, as well as intrinsic difficulties in conveying mitigating factors which might entitle them to a lesser sentence. ${ }^{21}$

Further, the danger which the Court in Atkins discerns is not simply that this class of defendant might not be able to make a convincing case against being sentenced to death, but that they are intrinsically vulnerable to being sentenced on the basis of aggravating factors they do not possess. Justice Stevens singles out two non-statutory aggravating factors which the mentally retarded may inadvertently promote, even in cases where these factors do not refer to objective facts. First, the "demeanor [of mentally retarded defendants] may create an unwarranted impression of lack of remorse for their crimes." ${ }^{22}$ Second, citing the previous Court case of Penry v. Lynaugh (in which the constitutionality of executing the mentally retarded had been upheld), ${ }^{23}$ Justice Stevens remarks that "reliance on mental retardation as a mitigating factor may ... enhance the likelihood that the aggravating factor of future dangerousness will be found by the jury." ${ }^{24}$ As will be discussed further below in connection with the penal goal of "incapacitation", these two aggravating factors have amongst the strongest influence on capital jury deliberations. There is therefore a real danger, the Court concluded, that juries might mistakenly believe the characters of mentally retarded defendants to be such that they should be executed, when in fact this is not the case.

Likewise, in Roper, Justice Kennedy does not rule out the possibility that a juvenile might possess the kind of culpability which means that if they commit a crime of demonstrable depravity, state execution would be a proportionate response. As with Justice Stevens in Atkins, however, Kennedy expresses concern at the epistemological difficulty faced by the jury in ascertaining whether the person in the dock satisfies these criteria. Kennedy notes that the details of a crime will often overshadow considerations about the offender's age. "An unacceptable likelihood exists that the brutality or cold-blooded nature of any particular crime would overpower mitigating arguments based on youth.." ${ }^{25}$ Moreover, "[i]t is difficult even for expert psychologists to differentiate between the juvenile offender whose crime reflects unfortunate yet transient immaturity, and the rare juvenile offender whose crime reflects irreparable corruption." ${ }^{26}$ As a result of these epistemic obstacles, "[w] hen a juvenile offender commits a heinous crime ... the State cannot extinguish his life and his potential to attain a mature understanding of his own humanity."27 When the defendant is under 17 years old, there is no certain and definitive way by which to assess whether his apparent depravity is a permanent and essential part of his character, or part of a temporary stage in his development as a person. In those circumstances, the Court ruled, the risk of executing someone for whom

\footnotetext{
Atkins v. Virginia, 536 U.S. 304, 320 (2002).

Id. at 321.

Penry v. Lynaugh, 92 U.S. 302 (1989).

Atkins v. Virginia, 536 U.S. 304, 321 (2002)

Roper v. Simmons, 543 U.S. 551, 573 (2005).

Id.

Id. at 574-75.
} 
death would not be a proportionate punishment is simply too great.

In Atkins and Roper, the Court thus expressed an acute awareness of the epistemological difficulties involved in definitively determining defendants' depravity. In Roper, the Court expressed its concern that it could not be objectively known whether a youth's character was beyond repair, while in Atkins, it similarly noted the difficulties faced by mentally retarded defendants in making known their lack of depravity to the jury. For the Court in both cases, the condition of the defendants in question raises considerable doubts over whether their actions (however heinous) actually reflected an essentially depraved character. Whether someone possesses such a definitively depraved character may be more difficult to discern from their actions where they are susceptible to following others (Roper and Atkins), do not engage in reasoned deliberation prior to acting (Atkins), or have a character which is developing and malleable, rather than fixed and "irreparable" (Roper). The current Court thus appears conscious of the danger that a jury, focussing on the details of a defendant's act (Roper), or their dangerous appearance (Atkins) might make incorrect inferences from this regarding the depravity of the defendant's character and consequently sentence him to an undeserved death. The irrevocability of death as a judicial sentence therefore requires that the Court take additional safeguards to ensure that the decision to inflict this penalty is the correct one, particularly in regard to categories of defendant who are so vulnerable to being misjudged that they should not be eligible for the state's ultimate punishment.

\section{SUMMARY}

Through these cases, the U.S. Supreme Court has sought to interpret the Eighth Amendment's ban of "cruel and unusual punishments" in relation to the state's ultimate penalty. In regard to particular classes of defendant, such as children (Roper), or the mentally retarded (Atkins), the Court has sought to rule on whether death is likely to be a proportional and purposeful punishment, as well as whethergiven the condition of these defendants - such a determination can be reliably and accurately gauged. ${ }^{28}$ Although (as will be discussed further below) the Court's rulings do occasionally gesture towards the nature which would be required for the death penalty to be a proportional punishment, the overall approach has thus been to selectively rule on cases where the death penalty would be disproportionate (or "cruel"), rather than seeking to provide comprehensive answers as to precisely when capital punishment would not be disproportionate or purposeless.

This article will now proceed to explore a different approach. Rather than asking whether, given the nature of certain categories of human defendant, the death penalty is constitutional in their case, I will begin by asking what - given the nature of the U.S. death penalty-one must believe about human beings per se for death to be a proportional and purposeful human punishment. The answers to this, I will argue, undermine the current judicial assumption that capital penal goals such

28 The Court's Eighth Amendment jurisprudence, of course, also involves many other aspects, such as how a punishment is determined to be "unusual" or violative (following Trop v. Dulles, 356 U.S. 86 (1958)) of society's “evolving standards of decency". Despite their importance, these aspects of the Court's approach lie outside the narrower focus of this article. 
as deterrence or retribution are entirely "secular" in nature. ${ }^{29}$ On this basis, a new ethico-legal challenge to the U.S. capital justice system will be proposed: namely, that the beliefs required for the U.S. death penalty's proportional and purposeful instigation are not congruent with the requirements of legal due process.

\section{The Penal Goals of the State's Ultimate Punishment}

\section{A. DETERRENCE}

Within the philosophy of criminal punishment, deterrence is often divided into two categories: general deterrence and specific (or individual) deterrence. ${ }^{30}$ While the former concerns the minds of prospective criminals within the general population, the latter focusses on the inhibitive effect of punishment on the future plans of the individuals in the dock. With the death penalty, it should be clear that only "general deterrence" is relevant. Following state execution, the defendant is not inhibited from committing further transgressions, so much as prevented from ever doing anything again. ${ }^{31}$ General deterrence (hereafter referred to just as deterrence) concerns the harm which others, through their criminal actions, might do if those who have previously done the same kind of action are not seen to be punished. Punishment towards this end, it is hoped, will sufficiently move potential criminals so that they abstain from unlawful acts which they would otherwise perform if the threat of punitive consequences was absent. ${ }^{32}$

Deterring punishment need not be directed at the harm that the defendant has done, but at the harm which his actions had the potential to inflict (and may still have if done by someone else in the future). The penal goal of deterrence, it may be argued, lies behind the Court's reservation of capital punishment for certain non-homicidal acts which the Court (somewhat disingenuously) has termed "offenses against the State." 33 While simultaneously ruling that capital punishment was an unconstitutionally disproportionate punishment for child rape, the Court in Kennedy v. Louisiana (2008) lists "treason, espionage, terrorism, and drug kingpin activity" as examples of this type of crime. ${ }^{34}$ Such crimes, it may be observed, do not necessarily cause death (or even severe disruption) to the lives of others.

$29 \quad$ See e.g., Holberg v. State, 38 S.W.3d 137 (Tex. Crim. App. 2000) (rejecting a claim that the Texan death penalty violated the Establishment Clause of the First Amendment); Hanson v. State, 55 S.W.3d 681 (Tex. Ct. App., 2001); Hogan v. State, 139 P.3d 907, 917 (Okla. Crim. App. 2006), adhered to on reh'g (June 28, 2006).

30 See, e.g. Rob Canton, Why Punish? An Introduction to the Philosophy of Punishment 35-37 (2012).

31 The penal goal of incapacitation which is relevant here will be discussed separately below.

32 For a contemporary proponent of deterrence as the justification for capital punishment, see Ernest van den Haag's contributions in Ernest Van den HaAg \& John Phillips Conrad, The Death Penalty: A Debate (1983).

33 See Kennedy v. Louisiana, 554 U.S. 407, 437 (2008); See also Heidi M. Hurd, Death to Rapists: A Comment on Kennedy v. Louisiana, 6 Oнго St. J. CRiм. L. 351, 351 n.2 (2008).

34 Kennedy v. Louisiana, 554 U.S. 407, 437 (2008). 
However, it is arguably in the nature of these acts that they have the potential to cause widespread disruption, and even threaten the fabric of the socio-political community. It is therefore imperative (from a fearful or mistrustful perspective) that those who might otherwise be motivated to perform these actions be inhibited from doing so through the institution of legal punishment. Through deterring others in this way, the state acts in defence of those within society who have not yet become victims. ${ }^{35}$ Understood through this lens, the goal of deterrence includes a proportionality principle loosely analogous to that of self-defence: the means of deterrence should only be as severe as is necessary to deter further harm from occurring.

With non-capital criminal punishment, the establishment of particular punishments for the purpose of deterrence intuitively makes sense. One can easily imagine that if there were no jail sentences, for instance, an increase in criminality would ensue. The anthropological assumptions in support for this are of an empirical, readily observable nature: namely, that as Jeremy Bentham wrote in the opening lines of his The Principles of Morals and Legislation, human action is "under the governance of two sovereign masters, pain and pleasure." 36 Someone may be deterred following their experience of certain consequences after performing certain actions, or as a result of observing the consequences which befall others and inferring from this what might happen to oneself. In either case, the operating principle behind deterrence is that human beings may be cowed from doing what they otherwise might have done by the threat that this action would result in them suffering. As Jeffrie Murphy puts it, "[p]unishment as deterrence is essentially a system of threats, and threats appeal...to our capacities for fear grounded in self-interest." 37

In the case of non-capital punishments, the fear elicited is usually either of being financially penalized (through the imposition of a fine), or of being deprived of liberty by being forced to spend a period of one's life (or even the remainder) in prison. To reiterate, all that is required anthropologically here is that human beings, akin to other animals, are capable of anticipating the possible consequences of their actions, and will ordinarily desire to avoid these consequences if they involve physiological hardship.

The assumptions involved in positing the death penalty as a deterrent, however, are different. As Justice Brennan pointed out in Furman v. Georgia, underlying the logic of deterrence in capital cases is the assumption that "a particular type of potential criminal" exists, and is such that they would not be sufficiently deterred by the possibility of life incarceration. ${ }^{38}$ Only the prospect of death will make them reconsider their actions. Justice Brennan expressed the opinion that "[o]n the face of it...the assumption that such persons exist is implausible." ${ }^{39}$ A similar observation is made by Justice Kennedy (in relation to youths) in Roper v. Simmons. ${ }^{40}$ Assessing

\footnotetext{
35 This is a distinguishing point between deterrence and retribution, where the state acts on behalf of those who are currently victims of that particular criminal.

Jeremy Bentham, The Principles of Morals and Legislation 1 (1879).

JefFrie G. Murphy, Getting Even: Forgiveness and Its Limits 43 (2003).

Furman v. Georgia, 408 US 238, 301 (1972).

Id.

40 Justice Kennedy writes that "To the extent the juvenile death penalty might have residual deterrent effect, it is worth noting that the punishment of life imprisonment without the
} 
the truth of this claim remains the remit of another project. The question asked here is: what beliefs are necessary concerning human beings for the death penalty to be construed as an efficacious and necessary (or proportional) deterrent in the context of contemporary society? Those who hold capital punishment to be permissible must implicitly believe that human beings, in general, are such that fear is necessary for social control. Moreover, they must hold that for some human beings, fear of even the longest deprivation of freedom-including complete separation from their society, friends and family - will not be sufficient to stop them from committing harm to others; their nature is such that the existential threat of state execution is required. Such human beings, it might be observed, would seem to present considerable danger to the safety of others within society.

Deterrence applies to calculated, premeditated, deliberative acts. Acts which are the result of a spontaneous, impulsive or compulsive agency cannot, by their very nature, be deterred. The degree of rational and deliberate calculation presupposed by the rationale of deterrence is, moreover, considerable. Deterrence supposes a mentality which constantly calculates the possible outcomes of a given situation, calibrates desires, assesses personal goals, tempers passions, and weighs long-term interests against short-term interests prior to taking action. In his seminal essay, 'Reflections on the Guillotine', the existentialist moral philosopher Albert Camus thus claims that "[f]or capital punishment to be really intimidating, human nature would have to be... as stable and serene as the law itself."

In the context of current U.S. capital proceedings, the deterrable subject's calculation must also consider the fact that (unlike in Camus' France, perhaps), capital punishment law resembles a highly contingent and multi-variable process, rather than a "serene" law from which a certain outcome is assured. Having been charged with a capital crime, a defendant must be found guilty of this crime "beyond a reasonable doubt" by a jury of his peers. Even if this occurs, however, death may not be the awarded punishment. Since Woodson v. North Carolina (1976), a death sentence cannot automatically follow from a defendant's conviction, regardless of the crime. Mandatory death sentences, the Court has ruled, are unconstitutional. ${ }^{42}$ The implication of this for deterrence is that the death penalty cannot be assumed to follow a guilty verdict, but must instead be considered as a possible, contingent consequence of one's crime, alongside other lighter penalties such as life imprisonment. The probability of being arrested for his crime, found guilty, and given death must also be weighed by the criminal together with other contingencies, such as the possibility that he will be successful in any subsequent legal appeal against his prospective death sentence. In addition to being intrinsically dangerous therefore, the penal goal of deterrence supposes that the prospective criminal is highly calculating and deliberative.

The form of the modern state executions is also relevant here. In 'Reflections on the Guillotine', Camus suggests that the private format of state executions indicates that the state does not truly believe in capital deterrence. He remarks, "[h]ow can a furtive assassination committed at night in a prison courtyard be exemplary? At most, it serves the purpose of periodically informing the citizens

possibility of parole is itself a severe sanction, in particular for a young person.” Roper v. Simmons, 543 U.S. 551, 572 (2005).

41 Albert Camus, Resistance, Rebellion and Death 144 (Justin O’Brien trans., 1961).

42 Woodson v. North Carolina, 428 U.S. 280, 304 (1976). 
that they will die if they happen to kill-a future that can be promised even to those who do not kill." ${ }^{43}$ Since its last public execution in 1936, U.S. executions have usually had few public witnesses. ${ }^{44}$ As Hugo Bedau observes, "[t]he relative privacy of executions nowadays (even photographs of the condemned man dying are almost invariably strictly prohibited) means that the average American literally does not know what is being done when the government...executes a criminal." ${ }^{45}$ Camus may be correct that such a lack of public visibility robs state execution of its efficacy as a deterrent. The question asked here, however, is what sort of criminal agency would be effectively deterred by this mode of threatened violence?

Devoid of concrete public visibility, the effectiveness of today's death penalty as a deterrent relies more on the abstract concept of the state's deadly agency towards would-be criminals. Individuals must be cognisant not simply that death may occur after their acts (which, as Camus points out, is guaranteed for everyone), but that this end could be prescriptively brought against them by the state. To believe that the U.S. death penalty could be an effective deterrent therefore supposes that the deterrable criminal subject is capable of cognising - and being motivated by - this abstract concept of state agency, instead of their immediate sensory experience, and prior to otherwise committing a horrendous crime. Here again, the anthropological assumptions necessary for death to be a good punishment include a high level of calculation and deliberative rationality.

\section{B. RETRIBUTION}

Retribution is a punitive response to what another "deserves" because of their actions. Intrinsic to this logic is a principle of proportionality. Any given punishment must be a proportional response; it must "fit the crime." ${ }^{46}$ An important prima facie question here is what is being weighed on retribution's scales. This, in turn, will be affected by what the object of retributivism is. In Getting Even, Jeffrie Murphy makes a useful distinction between "grievance retributivism" and "character retributivism." ${ }^{\prime 47}$ The former is directed at the harm which has been caused by the defendant's actions, while the latter concerns the defendant's character as a human being.

Applied to the question of proportionality in retribution, grievance retributivism will ask whether the harm inflicted upon the criminal by particular punishment is proportional to the harm that they have caused through their actions ${ }^{48} \mathrm{~A}$ commonly

43 Camus, supra note 41, at 136.

44 For a U.S. legal scholar who provides an overview of how U.S. death penalty has developed in respect to public (in)visibility, as well as providing an argument in favour of increased media access into the procedure, see John D. Bessler, Death In The Dark: Midnight Executions In America (1997).

45 Capital Punishment 26 (James A. McCafferty ed, 2017).

46 For a recent and well-articulated defence of retributivism's logic, see e.g. Louis Pojman, The Case for Capital Punishment in Louis P. Pojman \& Jeffrey Reiman, The Death Penalty: For and Against 1-67 (2000).

47 Jeffrie G. Murphy, Getting Even: Forgiveness and Its Limits 43 (2003).

48 For apparent representatives of this perspective on retribution, see e.g., Richard W. Burgh, Do the Guilty Deserve Punishment?, 79 J. PHIL. 193 (1982); John Rawls, Two Concepts of Rules, 64 Phil. Rev. 3 (1955); John Braithwaite \& Philip Pettit, Not Just DeSERTS (1992). 
cited illustration of this is the biblical injunction of lex talionis: "an eye for an eye." Character retribution, on the other hand, while not ignoring the level of harm caused, will place its emphasis on whether a punishment is proportionate to the depravity and culpability of the defendant. ${ }^{49}$ Both forms of retributivism presuppose that the defendant is morally responsible for their actions, in the sense of knowing right from wrong. Character retributivism, it should also be noted, does not necessarily deny the relevance of the harmfulness of a person's criminal action, particularly insofar as it may be indicative of their culpability. ${ }^{50}$ The difference therefore lies in the weight possessed by moral culpability in determining whether a retributive punishment is proportional. In order to help gauge whether the retributivism pursued through U.S. capital punishment is accurately identified as a "grievance" or "character" form of retributivism, it is first necessary to examine the motivations behind the pursuit of this penal goal.

\section{Outrage-Based Retribution}

In Gregg v. Georgia (1976), the Court stated that "capital punishment is an expression of society's moral outrage at particularly offensive conduct." ${ }^{51}$ Through this outrage, society expresses a reflexive belief that the crime which has been committed is "so grievous an affront to humanity" that its perpetrator deserves to be executed. ${ }^{52}$ This "instinct for retribution", the Court asserts, "is part of the nature of man, and channelling that instinct in the administration of criminal justice serves an important purpose in promoting the stability of a society governed by law. ${ }^{53} \mathrm{On}$ this view, capital retributive punishment derives its raison d'etre from the desires and dispositions of the individual human beings composing society. ${ }^{54}$

Correlating to this, one of the key reasons which the Court in Furman identifies for capital retribution is the need to avoid the consequences which might follow if these abovementioned community desires were not addressed. "When people begin

49 See e.g., J. Angelo Corlett, Responsibility and Punishment (2013); Joel Feinberg, The Expressive Function of Punishment, 49 THE Monist 397 (1965). For an account arguing that in fact only culpability matters, to the exclusion of resulting harm, see e.g., LARRY Alexander et Al., Crime And Culpability: A Theory of Criminal LaW (2009).

50 In ruling that victim impact statements were constitutional (overturning Booth v. Maryland), the Court thus stated that "We are now of the view that a State may properly conclude that for the jury to assess meaningfully the defendant's moral culpability and blameworthiness, it should have before it at the sentencing phase evidence of the specific harm caused by the defendant." Payne v. Tennessee, 501 U.S. 808, 825 (1991). Gregg v. Georgia, 428 U.S. 153, 183 (1976).

Id. at 184 .

Id. at 183.

54 In Spaziano v. Florida, Justice Stevens thus writes that "[death is] the one punishment that cannot be prescribed by a rule of law as judges normally understand such rules, but rather is ultimately understood only as an expression of the community's outrage" Spaziano v. Florida, 468 U.S. 447, 468-69 (1984) (Stevens, J., concurring in part and dissenting in part). Recognition of this unique penal grounding in community outrage, Justice Stevens argued, provides further justificatory force for the view that the jury (as representatives of the outraged community's conscience) should play the decisive role in capital sentencing, rather than government officials on the judicial bench. This view is replicated in Harris v. Alabama, 513 U.S. 504, 515-26 (1995) (Stevens, J., dissenting); Ring v. Arizona, 536 U.S. 584, 613-19 (2002) (Breyer, J., concurring.). 
to believe that organized society is unwilling or unable to impose upon criminal offenders the punishment they 'deserve', then there are sown the seeds of anarchy." ${ }^{55}$ This view - that criminal punishment may act as a conduit for emotions of anger, resentment or hatred - is not new: Plato's Athenian stranger in the Laws appears to express this view. ${ }^{56}$ Similarly, writing in the late nineteenth century, Sir James Fitzjames Stephen argues that retributive emotions rightfully have an institutional outlet in the criminal justice system, just as sexual passions have an outlet in the institution of marriage. ${ }^{57}$ The question remains, however, whether these emotions are to be regarded as an undesirable element of the human condition which must be controlled, or rather (as Fitzjames Stephen held) as normally-occurring, nonpathological and morally legitimate reactions to an offender's wrongdoing. ${ }^{58}$

Defenders of the normativity of the retributive emotions and their institutionalisation have argued that such emotions are necessary for the maintenance of a moral community, ${ }^{59}$ contain a "kernel of rationality", ${ }^{60}$ or in any case are an "ineliminable" dimension of human justice. ${ }^{61}$ Regardless, however, of whether the Court in Gregg envisions retribution as a brute fact of social necessity, or a normative feature of the moral landscape, the fact remains that what drives this penological goal is moral outrage. Indeed, not only is societal outrage the driving force of retribution in U.S. capital punishment; it is also its proper end. In ruling against the constitutionality of executing those who are mentally ill in Ford v. Wainwright (1986) for instance, the Court has implied that retribution involves a dialectical relation between the executee and the society on whose behalf he is being killed. ${ }^{62}$ In order for the latter to be retributively satisfied, the former must be able to recognise what is being done to him, by whom, and why. Consequently, the Court ruled in Ford that the societal outrage which underpins the retributive goal of capital punishment cannot be vindicated by the execution of a prisoner who has no awareness of the true nature of his situation. No execution should thus take place.

The Court has thus recognised communal moral outrage as the underpinning of retributivism in relation to U.S. capital punishment. Anger is not expressed at something merely having happened (the act), but at something having been done (the act in relation to its actor). This aligns with a common intuition that anger directed at an inanimate object cannot have the same logical and justificatory

Furman v. Georgia, 408 US 238, 308 (1972) (Stewart, J., concurring.).

See Plato, The Laws of Plato 260-64 (Book X) (Thomas L. Pangle trans., 1988).

57 James Fitzjames Stephen, A History of the Criminal Law of England (1883). For contemporary proponents of this view, see e.g., Susan Jacoby, Wild Justice: The Evolution of ReVEnge (1983); Michael S. Moore, The Moral Worth of Retribution, in Responsibility, Character, AND the Emotions 217 (1988).

58 The Court's ambiguity on this point can be seen in Justice Marshall's dissenting opinion in Gregg. See Gregg v. Georgia, 428 U.S. 153, 238-40 (1976).

59 See e.g., Walter Berns, The Morality of Anger, in For CAPITAL Punishment: CRime AND the Morality of the Death Penalty 151-59 (1979).

60 Robert S. Gerstein, Capital Punishment-'Cruel and Unusual'?: A Retributivist Response, 85 Ethics 75 (1974); See also Robert C. Solomon, A Passion for Justice: Emotions and the Origins of the Social Contract (1995).

61 Richard A Posner, Emotion versus Emotionalism in Law, in The Passions of LaW 317 (Susan A. Bandes ed., 1999).

62 Ford v. Wainwright, 477 U.S. 399, 409-10 (1986). 
force as that which is directed at the agency which moved the object-whether an individual, or a collective. As pointed out by P.F. Strawson, moral outrage and other "reactive attitudes" presuppose that their object possesses culpability in the form of self-determining agency. ${ }^{63}$ Such attitudes are predicated upon their objects having conscious control over their actions and apprehending, or being such that they could be expected to apprehend, the potential consequences of their acts.

Indeed, it may be argued that there is a direct correlation between the level of outrage which can be appropriately expressed, and the culpability of the agent towards which it is directed. Anger at something another person appears to have done is often immediately tempered if it later becomes apparent that the damage inflicted was accidental, rather than deliberate, or done by a different kind of agency altogether (for example, the household dog). Insofar as retributive punishment is driven by, and directed towards, the satisfaction of moral outrage therefore, the object of this punishment will never just be the harmful nature of the act; rather, it will always involve consideration of the personal and moral culpability of the agent - the mentality with which they perform their harmful acts. ${ }^{64}$

\section{The Weight of Death: An Especially Severe Punishment}

In assessing the proportionality of punishment for the purposes of retribution, a key consideration is the severity of the punishment in terms of its consequences for the recipient. In this respect, as we have seen the Court acknowledge through its recent rulings, death is unlike all other punishments. If retribution is concerned with the moral character and culpability of the criminal, then the decision of the jury will not simply follow from the empirical fact of what the defendant has done (although this is a legitimate part of its determination). Rather, the jury must decide what it believes the defendant's subjective condition and agency to be. This decision is made critical by the especially severe nature of death: its permanent and irreversible consequences for the defendant. As outlined above, in ruling that juveniles or the mentally retarded should not be executed, the Court itself can be seen to acknowledge the difference which death makes for retribution to be proportionally achieved. The irreversible consequences of death for its object, the Court has indirectly suggested, requires that capital defendants likewise be "irretrievably depraved" in character (Roper), as well for this depravity to be an essential rather than transient aspect of their character (Atkins; Roper), as opposed to a transient or contingent aspect of their personality when they committed the crime.

63 See Peter F. Strawson, Freedom and Resentment, 48 Proc. of THE Br. AcAD. 1 (1962). For a recent overview and critique of Strawson's position and those of his chief interlocutors on this issue, see e.g., John Deigh, Reactive Attitudes Revisited, in Morality and the EмотіоNs 196-216 (Carla Bagnoli ed., 2011).

${ }_{64}$ This critique may be applied to Jeffrie Murphy himself, who suggests that capital punishment need not necessarily be a condemnation of the defendant's character. See his Christianity and Criminal Punishment, in Jefrrie G. Murphy, Getting Even 95-115. For further discussion of the interrelationship between culpability and harm, see e.g., Frederick M. Lawrence, Punishing Hate 58-63 (2009). 


\section{The Weight of the State: An Especially Severe Punisher}

As the Court observed in Godfrey, not all conscious acts of killing are of the same severity; the moral culpability of the agent matters. Having outlined the Court's current appreciation for the qualitatively different nature of death as a penalty, and the permanently depraved criminal anthropology which is thus required for this punishment to be an instance of proportional retribution, I will now problematise the issue further by observing the difference made by the agency of the modern state ${ }^{65}$ As noted above, the explanatory ground of U.S. capital retribution is the outrage felt within civil society towards the perpetrators of particularly horrendous acts. In putting a criminal to death, the state serves as an expression and outlet of this societal outrage. Unlike individuals within society, however, the state as such is not an emotive agent; in conduiting society's outrage and the homicidal desire which accompanies this passion, the modus operandi of the state is intrinsically procedural and deliberative.

As a result of death's inherent severity as a punishment, state execution strives towards consistency, reliability and a sense of sobriety. As such, the practice has also necessarily assumed a methodical, bureaucratic nature. Since the mid-to-late nineteenth century, executions have taken place behind the walls of a jailhouse. ${ }^{66}$ Admittance is limited by the state, which also maintains the method of execution and exerts strict control over the schedule of the defendant's last 24 hours alive. The date and time of the defendant's execution is predetermined and made known to him well in advance, and the whole process is designed to proceed in a deliberate, controlled, intentional, and organised manner. This is a result of the nature of death, qua irrevocable, but also, it may be argued, due to the nature of the agency of the state, qua state.

With a few notable exceptions such as Camus (discussed below), the implications of state agency for the proportionality of a retributive punishment have not been explicitly recognised by either contemporary scholarship or the Court's jurisprudence. It may, however, be argued that these implications are implicitly acknowledged. Even the most fervent proponents of retributivism as a sufficient reason for punishment acknowledge that the mirroring of harm implied by the lex talionis principle of an "an eye for an eye" should not be strictly applied (or, at least, not without a significant effort to conceptually reinterpret this principle) ${ }^{67}$ For example, it is commonly assumed that the arsonist should not be punished

65 For recent philosophical literature generally supporting the assertion that collectives such as states have agency, see, e.g., Carol Rovane, The Bounds of Agency: An Essay in Revisionary Metaphysics (1997), Christian List \& Philip Petit, Group Agency: The Possibility, Design, and Status of Corporate Agents (2011), Deborah Perron Tollefsen, Group as Agents (2015), Raimo Tuomela, Social Ontology: COLLECTIVE INTENTIONALITY AND GRoup AgENTS (2016). The view broadly represented here supports the position that collective bodies such as states may be said to exercise agency, while not necessarily possessing phenomenological consciousness.

66 For a detailed and interesting historical account of changes to the American death penalty during this period, and the altered dynamic this brought about between the local community and the state, see Stuart Banner, The Death Penalty: An American History 168-205 (2002).

67 For an interesting and well-argued example of one such reinterpretation, see Jeremy Waldron, 34 Lex Talionis 25, Arizona L. Rev. 34 (1992). 
by turning his house into a state-sponsored bonfire. A central reason for this, it may be suggested, is that the character of these actions would become even more perverse if done by the state. Where arson might (to varying degrees) have been the result of an uncontrolled impulse, spontaneous desire or external influence (such as alcohol) when performed by an individual, a level of deliberation, awareness and intentionality would be exerted by the state which would intuitively make such an action unconscionable as a punishment. In contrast (it may be supposed) to the average arsonist, the state qua punisher acts with absolute clear-headedness and autonomy. As such, the state both completely lacks any attributes which (in the case of an individual) might mitigate culpability, and acts-out to a super-individual degree many of the aggravating or "wrong-making" qualities (to borrow Jeremy Waldron's terminology $)^{68}$ which would otherwise be considered quintessential hallmarks of criminal depravity.

In 'Reflections on the Guillotine', Camus addresses the question of the death penalty's alleged proportionality. With words which prefigure those of the Court in Furman and Gregg, Camus begins by asserting that capital punishment must be recognised for what it is: a retaliatory "instinct" within society that "whoever has put out my eye must lose an eye; and whoever has killed must die." ${ }^{\prime 69}$ Retribution "confers" legal status upon this instinct. ${ }^{70}$ Provided that the legitimacy of this instinct is conceded, its "quasi-arithmetical" calculus must then be inspected. ${ }^{71}$ Would this action, when performed by the state, be proportional to the crime of homicide?

Camus' answer is unequivocal: between individual and state killings, "there is no equivalence." 72 Capital punishment, Camus writes, "adds to death a rule, a public premeditation known to the future victim, an organization". ${ }^{73}$ Capital punishment, particularly in its modern format of meticulous state control, displays an extraordinary level of planning. Indeed, Camus claims it to be "the most premeditated of murders", with practically every experience which the defendant has in the hours preceding his execution being subject to his killer's control. ${ }^{74}$ Critics of the death penalty often point out that this state practice amounts to "killing in order to show that killing is wrong." In fact, however, the situation is far more asymmetrical than this. U.S. capital punishment is more akin to killing in the most controlling and premeditated way possible in order to show that premeditated killing is wrong.

In addition to this systemic planning, Camus highlights the distinctive harm inflicted by the state in this punishment. Both the defendant and his family are informed of the former's fate months in advance and must live with that knowledge, compounded by the dreadful uncertainty of whether a reprieve might be possible. This extended period of "devastating, degrading fear", Camus claims, is arguably "more terrible than death". ${ }^{75}$ On many U.S. "death rows" today, criminals awaiting

\footnotetext{
Id. at 35 .

Camus, supra note 41, at 150.

Id.

$I d$.

Id. at 151.

Id. (emphasis added).

Id.

Id. at 152 .
} 
execution may also be confined for up to 23 hours a day to spatial units in which they are completely isolated from other inmates, continuously monitored by state authorities, and subject to perpetual artificial lighting. Based on this assessment, it might be asked what sort of culpability is being exercised by the state when it puts an individual to death. Is not the sort of death inflicted by the state "materially" greater in depravity than other killings? If so, might not the aggravating factor found by the jury in Godfrey of an "outrageously or wantonly vile, horrible and inhuman" act also apply to its homicidal acts? ${ }^{76}$ And finally, what does this (together with our previous considerations) imply for the anthropology of capital punishment? A brief summary of this section may help to clarify the import of these questions.

\section{Summary}

The objective of this article is not to argue that the death penalty is disproportional as a retributive punishment per se. Rather, the aim has been to ask what needs to be presumed about the nature of the criminal defendant in order for the death penalty, given its particular nature, to be proportional.

What sort of anthropology is needed to balance retribution's scales when death is the punishment? A sketch of this answer can arguably be discerned from the U.S. Supreme Court holdings outlined above. Firstly, capital punishment is distinct from other punishments due to its severity, which includes the irreversible nature of the harm it inflicts on the defendant. As such, for death to be a proportional punishment, the defendant's depravity must be "materially" greater than other offenders (Godfrey; Atkins), the consequences of his actions "beyond repair" (Coker), and his character "irretrievably depraved" (Roper). Secondly, capital punishment, qua homicide by the state, is by its nature the most deliberate, methodical and controlled infliction of harm possible on a defendant. In killing a convicted criminal, the state exercises a self-determination and conscious control of the situation which is absolute. As a result, it may be argued that it can only be a proportional instance of retribution for those whose culpability displays a kindred level of wilful initiative and rational calculation (Atkins; Roper). The absolute nature of the state's intentionality and deliberateness in killing arguably requires the defendant's culpability and depravity to be correspondingly complete. Not only must the defendant's character be "beyond repair", but it must also be absolute in its brokenness for death by state execution to be a proportional punishment.

As the proportionality of retributivism in U.S. capital punishment turns on the moral culpability of the criminal, moreover, it is not (and cannot be) an issue which is determinable on the basis of evidence. The defendant's character must be believed to be such that the scales of retribution are balanced and death an appropriate punishment. As detailed above, in Atkins v. Virginia Justice Scalia rhetorically asks "[b]y what principle of law, science, or logic can the Court pronounce that [the jury's judgment based on society's moral outrage] is wrong?", before observing that "[t]here is none." ${ }^{.77}$ From the perspective of grievance retributivism (as discussed

\footnotetext{
76 It may here be argued that in practicing capital punishment, the state kills not simply as means of achieving retribution, but out of necessity, insofar as its act is as one of selfdefence against an aggressor. The legitimacy of this justification, which has been termed the penal goal of "incapacitation", will be discussed below.

77 Atkins v. Virginia, 536 U.S. 304, 351 (2002).
} 
above), this is a valid point: outrage over the consequences of someone's conduct cannot be objectively falsified, scientifically or otherwise. However, Scalia's observation may also be instructive under the auspices of character retributivism. Whether or not the defendant deserves to be executed according to the demands of retributive justice is not a matter which can be assessed empirically. Rather, it is a judgement of the defendant's character as a human being, which implies belief in a certain philosophical anthropology.

The central point here is arguably inadvertently strengthened by two reductio ad absurdum arguments which Scalia makes in Atkins and Roper v. Simmons. In response to the Court's ruling in Atkins that mentally retarded persons face a "special risk" of being sentenced to death by the jury when their level of culpability or depravity does not warrant this punishment, Scalia comments that "I suppose a similar 'special risk' could be said to exist for just plain stupid people, inarticulate people, even ugly people." 78 These somewhat flippant remarks belie what, from the Court's perspective, should arguably indeed be a serious concern. Once it is accepted that an essentially and completely depraved character is required in order for capital punishment to be proportional, a serious epistemological difficulty is raised not only in the case of those who are stupid, inarticulate and ugly, but in all cases.

Similarly, in Roper, Scalia writes that "[n]or does the Court suggest a stopping point for its reasoning... Why not take other mitigating factors, such as considerations of childhood abuse or poverty, away from juries as well? Surely jurors 'overpower[ed]' by 'the brutality or cold-blooded nature' of a crime...could not adequately weigh these mitigating factors either." ${ }^{\text {" }} 79$ From the perspective of character retributivism, this concern is again well-founded. Far from being absurd then, Scalia's reductio does not go far enough.

\section{INCAPACITATION}

In addition to the commonly cited purposes of deterrence and retribution, another penal aim of capital punishment should be mentioned: the incapacitation of offenders in response to the threat they pose to society. Before critiquing the Court's position in Atkins v. Virginia that executing the mentally disabled does not serve the penal goals of deterrence or retribution, Justice Scalia writes that " $[t]$ he Court conveniently ignores a third social purpose of the death penalty [in Gregg v. Georgia] - incapacitation of dangerous criminals and the consequent prevention of crimes that they may otherwise commit in the future." ${ }^{80}$ The goal of incapacitation may be seen as analogous to an individual practicing self-defence. In removing an offender from its ranks, or by ensuring in some other way that they cannot reoffend, society pursues the common good of its members.

This rationale, which Camus notably described as the only "frontier" on which "discussion about the death penalty is legitimate", ${ }^{81}$ is often overlooked, despite its historic status as a rationale for capital punishment amongst even those (such as

Id. at 352.

79 Roper v. Simmons, 543 U.S. 551, 621 (2005) (citing Atkins v. Virginia, 536 U.S. 304, 321(2002)).

80 Atkins v. Virginia, 536 U.S. 304, 350 (2002).

81 CAmus, supra note 41 , at 168. 
Camus) who would otherwise argue against the practice. ${ }^{82}$ Today, the logic of the death penalty as the incapacitation of criminal threats can be seen to have a latent, underlying and persistent appeal in U.S. Supreme Court jurisprudence.

\section{The Court's Jurisprudence of Dangerous Capital Defendants: Coker, Ramos and Tison}

In Coker v. Georgia (1977), the U.S. Supreme Court ruled that it would be a violation of the Eighth Amendment to execute someone for the non-capital crime of rape ${ }^{83}$ In his dissenting opinion, Chief Justice Burger pointed out that "by his life pattern, Coker has shown that he presents a particular danger to the safety, welfare, and chastity of women, and, on his record, the likelihood is therefore great that he will repeat his crime at the first opportunity." 84 Burger continually emphasises the defendant's status as a "continuing danger to the community". This danger, Burger writes, is "abundantly clear" from the defendant's demonstrable "propensity for life-endangering behavior". ${ }^{85}$ Rejecting lex talionis" "primitive" retributive metric of "a life for life, eye for eye, a tooth for tooth", Burger argues that, even where defendants have not committed a homicide, definitive weight may be placed on their "criminal activity which consistently poses serious danger of death or grave bodily harm." ${ }^{\prime 86}$ Under Burger's view, the state is justified in killing demonstrably dangerous individuals not only on the retributive basis of what they have done, but according to what they might do if left at liberty in the future.

Burger's opinion in Coker did not represent the Court, which ruled that the talionic principles of retributive proportionality meant that death was not an appropriate punishment for non-homicidal crimes. Burger's insistence on the centrality of the defendant's dangerousness may, however, be regarded as a useful backdrop to the Court's subsequent decisions in California v. Ramos $(1983)^{87}$ and Tison v. Arizona (1987). ${ }^{88}$

In California v. Ramos the Court (led by Justice O'Connor) upheld a mandatory instruction to the jury (the "Briggs instruction") in California, unique to that state, which informed the jury that if the defendant received life without the possibility of parole rather than the death penalty, a possibility existed that his sentence might be commuted by the governor to life with the possibility of parole at some point in the future. ${ }^{89}$ Rejecting the assertion that the Briggs instruction was too speculative in nature for the jury to consider, the Court ruled that this instruction allowed the jury "to assess whether the defendant is someone whose probable future behaviour makes it undesirable that he be permitted to return to society, thus focusing the jury

82 For another example of this, see e.g., the eighteen century critic of capital punishment, Cesare Beccaria in Cesare Beccaria, An Essay on Crimes and Punishments 70 (Adolph Caso ed., 1992).

83 Coker v. Georgia, 433 U.S. 584 (1977).

$84 \quad I d$. at 606.

$85 \quad I d$. at 610.

$86 I d$. at 620.

87 California v. Ramos, 463 U.S. 992 (1983).

88 Tison v. Arizona, 481 U.S. 137 (1987).

89 California v. Ramos, 463 U.S. 992 (1983). 
on the defendant's probable future dangerousness." ${ }^{90}$ By pointing out that if not executed, a possibility (however slim) exists that the defendant will one day return to society, California's Briggs instruction arguably encouraged significant weight to be given to the defendant's future dangerousness during the jury's considerations on whether he should be put to death. In sanctioning the instruction, the Court in Ramos can clearly be seen to recognise the importance placed upon the consideration of the defendant's future dangerousness by the capital sentencing jury. ${ }^{91}$

In Tison v. Arizona, the defendant, Gary Tison, had participated in a prison break, during which a prison officer was killed. The question before the Court was whether an intention to kill (which Tison lacked) was necessary to sentence him to death for the officer's death, which Tison did not directly cause, but was instead an accomplice to the crime in which the death had occurred. ${ }^{92}$ Writing again on behalf of the Court in Tison, Justice O'Connor stated that although consideration of the defendant's mental state remains essential for determining criminal culpability, "[a] narrow focus on the question of whether or not a given defendant 'intended to kill,' however, is a highly unsatisfactory means of definitively distinguishing the most culpable and dangerous of murderers. ${ }^{\circ 3}$ Immediately of note here is the apparent conflation O'Connor makes of defendants' culpability (on the one hand) and dangerousness (on the other), rather than treating them as separate concepts relating to the separate penal goals of retribution and incapacitation, respectively. The central subject of the Court's opinion is the culpability of defendants, such as Tison, who fall short of an intention to kill. However, at the roots of this discussion a thinly disguised concern for the dangerousness of defendants - rather than their personal culpability — can be discerned.

For example, in making the case that those such as Tison are eligible for the death penalty, O'Connor points out that many who intend to kill are not in fact criminally liable (for instance, those who successfully claim their actions were pursuant to self-defence), while "some nonintentional murderers may be among the most dangerous and inhumane of all." $"$ This telling pivot away from the culpability of criminals for any specific crime, to the dangerousness of their natures, arguably underlines a crucial observation made by Justice Brennan in his dissenting opinion: unlike the above hypotheticals cited by O'Connor, not only did Gary Tison not intend for anyone to die; he did not (directly) cause anyone's death. ${ }^{95}$ While it may

\section{Id. at 992.}

91 Ramos concerned a jury instruction unique to California. However, the same recognition of future dangerousness's centrality to capital sentencing can also be discerned in the later case of Simmons v. South Carolina, 512 U.S. 154 (1994). In Simmons, the Court ruled that wherever future dangerousness is raised as consideration in a capital case, the jury should be informed that if not put to death, the defendant will not be eligible for parole. This is in recognition of the fact that, as Justice O'Connor observes in her concurrent opinion in Simmons, "[w] hen the State seeks to show the defendant's future dangerousness...the fact that he will never be released from prison will often be the only way that a violent criminal can successfully rebut the State's case" Simmons v. South Carolina, 512 U.S. 154, 177 (1994). See also Shafer v. South Carolina, 532 U.S. 36 (2001).

92 Tison v. Arizona, 481 U.S. 137 (1987).

93 Id. at 157 (emphasis added).

94 Id. (emphasis added).

$95 \quad I d$. at 169. 
be true that an intention to kill is not sufficient for the criminal culpability required for retribution to be proportional, Brennan notes that it is nevertheless necessary. ${ }^{96}$ In ruling that someone may be executed on the basis of his subjective state of a "reckless indifference to the value of human life", ${ }^{97}$ the Court thereby passed a ruling which could not be justified on a purely backward-looking, retributive basis; future dangerousness must be invoked.

\section{The Proportionality of Incapacitation}

Although rarely stated, the penal goal of incapacitation (akin to retribution) involves an assessment of how proportional a punishment is, given the facts of a particular situation..$^{98}$ The logic here is analogous to that of an individual's legal claim of self-defence. A person may only be justified in defending themselves if their use of force, or means of self-defence, is proportionate to the severity of the threat they face and what action is necessary to stop it. So too, a state practice aimed at incapacitating offenders will only be proportionate if it does not use a force which is greater than what is needed to quell the threat posed by the offender.

As with the goals of both retribution and deterrence moreover, the existence of a state prison-system, and the possibility of lifelong incarceration, necessarily also bear upon the presumptions which must be made about the criminal's nature for capital punishment to be a proportionate exercise of incapacitation. The existence of prisons entails that facilities are available where defendants can be detained outside society and treated for as long as it is necessary for their dangerousness to subside. This possibility of spatially containing the defendant for an indefinite period of time arguably means that, as with the anthropological assumptions concerning the defendant's culpability and depravity needed for retribution (Roper), the defendant's dangerousness (which follows automatically, one might assert, from this depravity) must be an essential and permanent feature of his condition. As Camus maintains, there is "no room for imagining that [the defendants to be incapacitated] can ever repent or reform", with the result that "[ $t]$ hey must merely be kept from doing it again, and there is no other solution but to eliminate them. ${ }^{" 99}$ Furthermore, while incarcerated, there is no possibility of the defendant being a threat to the wider community. In order for incapacitation to require death therefore, it must arguably be assumed that the criminal will continue to pose a legitimate threat to society even while in prison. Put simply, it must be believed that the defendant's very existence is dangerous, and that this dangerousness cannot be nullified by physical restraint, spatial containment, ${ }^{100}$ or institutional treatment. For incapacitation is

Id. at 173 .

Id. at 157 .

98 See e.g., John F Stinneford, Rethinking Proportionality Under the Cruel and Unusual Punishments Clause, VA. L. Rev. 916 (2011).

99 Camus, supra note 41, at 168.

100 It might be argued, following Ramos, that "life without the possibility of parole" in fact only means life "without the possibility of parole, barring the future possibility of executive clemency." However, (as the dissent in Ramos points out), the same qualifier could conceivably be added to any sentence, including death. Another possible counterpoint is that prisoners may escape while still alive, although in contemporary society this is such a remote possibility that it can arguably be discounted as a serious consideration. 
to be proportionally achieved by the death penalty, it must be believed that the criminal, if allowed to live, will always be dangerous. ${ }^{101}$

\section{Summary: Penal Goals and the Philosophical Anthropology of CAPITAL PUNISHMENT}

Due in part to the existential severity of death, the nature of the capital punisher (qua state), and the existence of imprisonment as an alternative sentence, to believe that there may be a hypothetical situation in which it is possible for the death penalty to be an appropriate punishment, non-empirical anthropological commitments must be presupposed. For capital punishment to fulfil the penal goal of deterrence, one must make assumptions about the nature of those within society; for retribution, that the one to be executed possesses a moral culpability which is "irretrievably depraved" (Roper) and essential to who they are as a person (Roper; Atkins); for incapacitation, one must believe that the very existence of the individual before them presents a permanent and irredeemable danger or threat to the community. Such beliefs rely on anthropological commitments which can be neither demonstrated nor disproven through inductive or deductive reasoning, and entail normative judgments regarding the value of others' lives. ${ }^{102}$ Owing to the irreversible nature of death as a judicial sentence, moreover, the epistemological certainty with which these judgements must be held must be of a qualitatively different order than that which is involved in sentences of correctable (or at least compensable) punishments. Whereas judgements in the case of non-capital sentences may be based on the sort of balance-of-probability analyses involved in answering many empirical questions, the certainty demanded by the terminal nature of a death-sentence is more akin to the non-probabilistic certainty associated with religious faith. The anthropology which underpins the death penalty is thus a kind of philosophical anthropology which, as such, cannot be tackled on a purely scientific or deductive basis.

In 'Christian Witness, Moral Anthropology, and the Death Penalty', Richard W. Garnett critiques modern legal discourse for being insufficiently attentive to the anthropological assumptions which underpin the constitutional debate over U.S. capital punishment. ${ }^{103} \mathrm{He}$ writes that "I believe that, for the most part, our nation's moral vocabulary, constitutional law, and political discourse - including its debates about capital punishment - rest upon the unsteady foundation of a flawed moral anthropology." 104 Garnett proceeds to advocate shifting away from this "flawed" foundation towards a Christian moral anthropology. Despite the ambitious nature

101 On a side note, one might suggest that a societal belief in such especial dangerousness is evidenced by the particular institutional measures commonly taken against capital prisoners. While on death row, these inmates are commonly placed in an isolated but constantly monitored cell for 23 hours a day, with prison security even more heavily increased on the day of their execution.

102 This point can be found in Camus, who acknowledges that the argument for and against the death penalty comes down to a belief about the nature of other human beings which cannot be objectively adjudicated. As he states, "[t] his is the point... where the arguments clash blindly and crystallize in a sterile opposition." CAMUs, supra note 41, at 169.

103 Richard W. Garnett, Christian Witness, Moral Anthropology, and the Death Penalty, 17 Notre Dame J.L. Ethics \& Pub. Pol'y 541 (2012).

$104 \quad I d$. at 555. 
of this challenge and the substantive contribution of his article, Garnett concludes that:

This essay is offered more as a prolegomena than a resolution. I am not yet sure what all this might mean, or what a shift in our anthropological premises and idiom might yield, in the context of the death penalty debate. ${ }^{105}$

Outside the work of philosophers such as Camus, Garnett's work remains notable for raising the issue of capital punishment's philosophical anthropology. This is particularly true within legal scholarship. Although the Court's rulings arguably do offer some insights into the sort of human nature required for death's proportionality as a punishment, the picture which emerges from these cases is piecemeal and fragmentary, insofar as the Court remains narrowly focussed on the culpability of particular defendants (Coker; Godfrey) or classes of defendant (Atkins; Roper), rather than on the (logically prior) question of what the proportionality of capital punishment requires human beings as such to be. Through this article's discussion of the penal goals of capital punishment and the anthropological assumptions they involve, I hope to have clarified how capital punishment might be approached more comprehensibly through the lens of philosophical anthropology. The potential implications for the U.S. debate over capital punishment, I submit, are stark: either the U.S. death penalty must be understood as depending upon a morally evaluative, non-empirical anthropology, or it must be conceded that, although this practice may indeed deter crime, exact vengeance or incapacitate criminals, it cannot claim to be a proportionate fulfilment of these penal goals for human beings.

\section{Conscientious Beliefs and the Impossibility of Capital Due Process}

One set of implications from this argument concerns the relationship between a proportionate and purposeful capital punishment (on the one hand) and the demands of legal due process (on the other). In one respect, this angle on the U.S. death penalty debate is not new. When the Court in Furman v. Georgia suspended capital punishment in 1972, it was partly pursuant to the view that the death penalty (as it was then practiced in certain U.S. states) did not meet the standards of impartiality or objectivity required by the Fifth and Fourteenth Amendments. ${ }^{106}$ Instead, the Court found that the process by which capital juries in Georgia reached their determinations was potentially discriminatory and capricious, resulting in an unacceptably high risk that defendants would be erroneously sentenced to death. This is contrary to the Due Process Clause of the Fifth and Fourteenth Amendments, the spirit of which requires

105 Id. at 558.

106 Furman v. Georgia, 408 US 238 (1972). For an article which has since sought to extend the Court's post-Furman Due Process jurisprudence so as to apply to capital punishment per se, see Joshua Herman, Death Denies Due Process: Evaluating Due Process Challenges to the Federal Death Penalty Act, 53 DePAul L. Rev. 1777 (2003). The proposed argument of the current piece differs from such scholarly attempts insofar as its starting point is the philosophical anthropology of capital punishment, combined with an appreciation for the Eighth Amendment requirements of proportionality and purposiveness. 
that the necessary constituents of a sentence be proved "beyond a reasonable doubt" on the facts of the case before criminal punishment is given. ${ }^{107}$ The Due Process Clause therefore sets a high bar of objectivity and certitude which, the Court in Furman ruled, the capital justice system was not reaching.

As Justice Douglas suggests in his concurrence in Furman, the Court's collective judgments in this case bore witness to an implicit connection between concern for equal protection and due process under the Fourteenth Amendment, and the question of whether something constitutes a "cruel and unusual" punishment under the Eighth Amendment. ${ }^{108}$ As discussed above, this implicit connection can subsequently be seen to resurface in the Court's rulings that certain defendants, such the mentally retarded (Atkins) or children (Roper), are particularly vulnerable to having aggravating characteristics falsely ascribed to them, and so to being unjustly sentenced to death. ${ }^{109}$ In making this determination, the Court recognised that its role as watchman for the death penalty's constitutionality may require asking whether one can objectively, reliably, and "beyond a reasonable doubt", determine that penal goals are fulfilled by the execution of particular classes of capital defendant.

The Court's post-Furman capital jurisprudence has thus implied a close connection between the Eight Amendment's prohibition on "cruel and unusual punishments" and the Due Process Clause of the Fifth and Fourteenth Amendments. As the Court stated in Coker v. Georgia (1977), it regards the Eighth Amendment as demanding that criminal punishment not be "purposeless" or "grossly out of proportion"; 110 rather, the enactment of a death sentence on the defendant must be capable of proportionally fulfilling a penal purpose, such as deterrence or retribution (Furman). The constitutional right to due process under the Fourteenth Amendment, meanwhile, demands that this determination can be fairly, reliably and unambiguously made.

The Court's rulings in favour of the defendants in Atkins and Roper, it was noted, thus turned on an epistemic difficulty: how can the culpability and essential character required for the death penalty's proportionality as a retributive punishment be reliably gauged by the jury, particularly where the defendant's courtroom presentation could be misleading? An appreciation of the uniquely essentialist demands of capital punishment's philosophical anthropology makes this difficulty both deeper and broader. I have argued that in order for state execution to be "deserved" (in the sense of being a proportional retributive punishment), the human being on trial must possess a culpability and character which is essentially and permanently depraved. To require that such a determination be "beyond a reasonable doubt" is intrinsically problematic, irrespective (pace Atkins and Roper) of the person's mental capacity or age. This is because the essentiality or permanence of someone's character is not conclusively demonstrable empirically. How then, it might be asked, can legal due process be guaranteed in any death penalty proceeding?

\footnotetext{
107 See In re Winship, 397 U.S. 358, 354 (1970) (Brennan, J., writing for the Court). More recently, see Victor v. Nebraska, 511 U.S. 1 (1994).

108 Furman v. Georgia, 408 US 238249 (1972) (Douglas, J., concurring).

109 In this dissent to the Court's approach in Atkins, Justice Scalia noted the Court's implicit tying of the Eighth Amendment to a Fourteenth Amendment concern for "due process". See Atkins v. Virginia, 536 U.S. 304, 352 (2002).

110 Coker v. Georgia, 433 U.S. 584, 591-92 (1977).
} 
This point may be illustrated with reference to one of Camus' most famous fictional works, The Stranger (L'Étranger). In this novel, Camus' anti-hero Meursault becomes the defendant in a capital trial, after deciding to shoot an Algerian man in cold blood. Through first-person narration, Camus presents Meursault as deficient in emotional responsiveness, empathy and consequential reasoning. He is paradigmatically sociopathic. As Meursault admits to the reader following the prosecutor's accusation that he showed no remorse or contrition for the crime, he is simply "far too much absorbed in the present moment, or the immediate future, to think back", akin (one might posit) to a non-human animal. ${ }^{111}$ As Camus' title suggests, Meursault is quintessentially unrelatable. Indeed, he seems almost deliberately engineered at times to circumvent the reader's sympathies. What this portrayal does serve to exemplify, however, is how even when such a seemingly strange and detached psyche is located within the courtroom dock, an epistemological chasm remains to be crossed in order to condemn the person to death. During his trial, Meursault's disposition on the day of his mother's funeral, whether he cried, how quickly he left, and whether he stopped at her grave or knew his mother's age, are all among the details used to determine the defendant's culpability for the murder. ${ }^{112}$ The most contingent and insignificant of circumstances, such as who offered whom coffee, thus take on a decisive significance. Meursault bathetically describes how

[a]fter asking the jury and my lawyer if they had any questions, the Judge heard the doorkeeper's evidence. On stepping into the box the man threw a glance at me, then looked away. Replying to questions, he said that I'd declined to see Mother's body, I'd smoked cigarettes and slept, and drunk café au lait. ${ }^{113}$

Although these are temporary moments in an individual's history of decisionmaking, they are elevated by Camus' prosecutor to demonstrations of an essentially depraved character: "a criminal at heart". ${ }^{114}$ The scene Camus describes is consciously parodic in nature. Most capital cases, it might be objected, turn on far graver and more disturbing details than one's social etiquette or choice of beverage. The thrust of Camus' account, however, remains pertinent; as between acts of small consequence (drinking café au lait) and those of greater significance (such as intentional and aggravated murder) there is a difference in degree, rather than kind. In either case, the agent's act results from her temporary subjective state. A person's essential nature or character, however, remains a different matter.

As Camus' L'Étranger prosecutor notes, "first, you have the facts of the crime; which are as clear as daylight. And then you have what I may call the night side of this case, the dark workings of a criminal mentality." 115 What Camus' novel implicitly invites the reader to ask is how such a transition from the former to the latter can ever be made. A person's actions, along with her outward demeanour and previous history (the "facts" of a case) are, in principle, empirically confirmable. A

\footnotetext{
Albert Camus, The Stranger 63 (Stuart Gilbert trans., 1954).

$I d$. at 56.

Id.

Id. at 60 .

Id. at 62 .
} 
person's essential character, on the other hand, is not. The objects of the judgments, moreover, are modally distinct: one concerns the contingent or accidental, the other that which is essential or permanent. To commandeer the term of another existentialist thinker, Søren Kierkegaard, there remains an "infinite qualitative difference" between the judgments which can be made about these respective objects. ${ }^{116}$ In this sense, insofar as the death penalty is constitutionally required to be a proportionate and purposeful punishment, every U.S. capital trial may be said to have just as much Eighth Amendment "due process" as that of Camus' café au lait drinking defendant.

Whereas the 1972 Furman Court tied its provisional judgment of capital punishment to the circumstances of the punishment's application at that time, it is here suggested that the death penalty, qua state-punishment of death, inevitably lies in tension with the demands of legal due process once the requirements of the Eighth Amendment are appreciated. Taken together, these Amendments constitute the horns of a constitutional dilemma for capital punishment. The Fourteenth Amendment stipulates that no person should be deprived of life "without due process of law"; the Eighth Amendment requirements of proportionality and purpose make such capital due process impossible. The anthropology of capital punishment supposes that some human beings, despite not possessing any features which would definitively demarcate them from the rest of humanity, are nevertheless essentially different in nature. This lies beyond the bounds of what any human being can empirically and reliably gauge - without arbitrariness, bias or caprice - about another person on the facts of her case. As such, the suggestion may be made that it is fundamentally at odds with the implicit requirements of legal due process. ${ }^{117}$

\section{CONCLUSION}

The arguments presented here represent only a new opening gambit in the ongoing ethico-legal debate over U.S. capital punishment. It will not have escaped notice that the novelty of this article's claims about the anthropology of capital punishment mean that its conclusions currently lack supporting legal precedent. Much of what has been said, furthermore, would benefit from further development. What I do hope to have demonstrated through this article, however, is how the internal secular logic for penal goals such as deterrence and retribution fundamentally breaks down when the punishment is death. For these aims to function in the context of the death penalty, the members of the jury must assume some degree of access into the subjective state of the defendant (retribution; incapacitation) or prospective criminals within society (deterrence), such that the character of these individuals

116 See Søren Kierkegaard, Practice in Christianity 28-29 (Howard V. Hong \& Edna H. Hong eds. \& trans., 1991); Søren KierkegaArd, The Sickness unto Death: A Christian Psychological EXPosition For Upbuilding AND AwAKENING 126 (Howard V. Hong \& Edna H. Hong eds. \& trans., 1980).

117 A loose (and consciously tongue-in-cheek) analogy might be made to the trial and execution of (alleged) witches, as occurred in Europe during the $16^{\text {th }}-18^{\text {th }}$ centuries. In both situations, it is the ontology of the accused - the state of her or his nature-which is ultimately on trial, resulting in an insurmountable difficulty for the prospect of legal due process. 
may be definitively judged as highly calculating (deterrence; retribution), critically dangerous (deterrence; incapacitation) and/or irretrievably depraved (retribution; incapacitation). Whether conceived in terms of the defendant's moral culpability or dangerousness, to sentence someone to death is to make a definitive judgment about who they are, rather than simply to make a probabilistic judgment about what they have done. The basis for this judgment goes beyond the empirical, so as to render it a fundamentally conscientious position. Such are the anthropological commitments required by belief in capital punishment's legitimacy as a proportional and purposeful punishment. On this basis, a new ethical and legal challenge to U.S. capital punishment has been suggested from the (in)compatibility of the beliefs required for its (Eighth Amendment compliant) instigation, with the demands of legal due process. Seen in this light, death is indeed different. 